\title{
How much is a scientist worth?
}

\author{
Pay and benefits for postdoctoral researchers
}

They are the perfect workforce-young,
mobile and fully prepared to work the sort
of hours that would immediately send
labourers in any industrialized country
out on strike. They are willing to move
around the world from one assignment to

'It is incomprehensible that you spend 10 years of your life educating yourself and then you are earning the same amount as a bus driver'

\begin{abstract}
beginning to feel the squeeze. The number of students opting to study natural sciences is decreasing, and senior scientists and politicians fear that academic research will soon face a real labour shortage.
\end{abstract}

more than scientists (Table 1). Studies from NATFHE, the British university and college lecturer's union, and the BETT Report, published in June 1999 by the Independent Review of Higher Education, Pay and Conditions, paint a similar picture for scientists in the UK and suggest that this situation is mirrored all over the world. 'In nearly every country in the world these three [clinical, engineering and law] are paid much more than the the next and, last but not least, they come cheap. These are not poor, migrant, manual workers, desperate to earn money to send home to their families in less-developed countries. This perfect workforce is an army of highly skilled, well-educated young professionals, often with more than 10 years of rigorous training at top universities worldwide: they are postdoctoral fellows. These underpaid, hard-working labourers represent the most creative members of the academic research community and possibly the most valuable intellectual capital of today's knowledgebased societies.

There is also a striking discrepancy between their value and their rights. While politicians and economists continue to stress the immense value of research in the natural sciences and the knowledge gleaned from it, this seems to mean little when it comes to funding the people who do the bulk of the work. To Sydney Cambridge, an American postdoc working at the Max-Planck-Institute for neurological science in Munich, Germany, 'it is incomprehensible that you spend 10 years of your life educating yourself and then you are earning the same amount as a bus driver'. He feels that although his salary is adequate for his own personal needs, it does not reflect the level of training he received and is too low. Indeed, the meagre level of postdoc salaries has been a recurring theme over the past few decades, but it is only now that science is

Table 1. Comparison of salaries for professionals in the USA

\begin{tabular}{l|c|} 
& $\begin{array}{c}\text { Median annual } \\
\text { income (in C) }\end{array}$ \\
\hline Lawyers and judges & $79,820.00$ \\
\hline Physicians & $73,320.00$ \\
\hline Mathematical and computer scientists & $60,268.00$ \\
\hline Engineers, architects and surveyors & $59,384.00$ \\
\hline Teachers, college and university & $58,552.00$ \\
\hline Executive and Administrative & $55,120.00$ \\
\hline Natural scientists & $51,792.00$ \\
\hline Source: Science and Engineering Indicators 2002, & \\
\hline The National Science Foundation & \\
\hline
\end{tabular}

Compared with their peers in engineering, law, medicine or business administration, natural scientists languish at the bottom of the salary league. In 1999, the median annual income of those working in the natural sciences in the USA was

average scientist', commented Tom Wilson, head of the universities department at NATFHE, commented.

These statistics represent average salaries for the whole of the academic spectrum, ranging from technician to

\section{The current situation of low salaries for postdocs is beginning to take its toll on academic science}

almost US\$10 000 less than that of mathematical and computer scientists. This imbalance was even higher when it was compared with the income of lawyers and judges, who, on average, earn US\$25000 institute director. Since no specific data are available on postdoctoral incomes in the natural sciences, a sample of salaries was taken from job advertisements posted on the EMBO database, in Nature and in 
Science. Although this is clearly not a thorough analysis, it provides a snapshot of the average salary a postdoc can expect to earn in various countries (Table 2). Switzerland sits comfortably at the top of the table, followed by the UK and Germany, whereas postdoctoral salaries in the USA seem to be surprisingly low compared with those in Europe. But this is somewhat misleading. For instance, with the exception of Washington, DC, New York City and the San Francisco bay area, living costs in the USA are often much lower than in Switzerland, the UK and Germany. Furthermore, in Britain and Germany, mandatory payments for health care and pension schemes must be paid as part of general taxation, which can eat into a considerable portion of the gross salary. These differences aside, this snapshot of salaries shows that postdocs are paid equally poorly around the globe.

Table 3 provides a more detailed overview of the fellowships awarded by various funding agencies in Europe, the USA and Canada. The lower figure is the salary paid to an unmarried postdoc with no children and no previous experience. If the salary is dependent upon geographical location, the lowest salary available has been selected. The higher numbers represent salaries for married postdocs with two children and at least 5 years of postdoctoral experience. If again dependent on geographical position, the highest salary available has been chosen. As also shown in the table, many fellowship programmes do not include health insurance and this in itself can devour a significant chunk of the basic salary, especially if the recipient is married and/or has children. They often do include family benefits, but the value of these varies enormously, and there is still a long way to go before pay accurately reflects these additional costs.

Many postdocs are increasingly unhappy with this situation. Kota Miura, a Japanese postdoctoral fellow at the European Molecular Biology Laboratory in Heidelberg, Germany, feels that a 'combination of low salaries and a lack of job security can put great pressure on postdocs'. Elsewhere, in a study conducted by Stanford University in 1999 (http://www.stanford.edu/group/supd/ survey $1999 . \mathrm{html}), 30 \%$ of its postdocs expressed dissatisfaction with the benefits they received and regarded this as one of the major disadvantages of their career choice. Nearly half of the postdocs questioned said that they could imagine that low salaries and benefits would discourage other researchers from going to Stanford. Consider that Stanford is one of the best universities in the world and that its rigorous entrance procedures mean a huge career boost for those accepted and the extent of the problem is clear. As this study also shows, it is not only low salaries that are the problem, but the lack of additional benefits for health care, child care and retirement schemes.

Indeed, a drawback to many fellowship schemes is the fact that contributions to retirement funds are rarely included. Even if the funding agency provides such payments, postdocs moving abroad are often left in the cold because many state pension schemes are not transferable between European countries, although they often are between EU member states and the USA. There are schemes that allow transfer of funds between EU member states, but information on these is not easy to find, and the majority of

The demise of this valuable resource of postdocs represents a great loss of scientific potential, creativity and progress

postdocs are unaware of them. Mobility is one of a postdocs' greatest assets, and a considerable number are willing to go abroad to gain international research experience but, as Antonio Coutinho, Director of the Instituto Gulbenkian de Ciência in Portugal, commented, 'as long as these problems [of inflexible pension schemes] are not solved, then you can forget about mobility'.

The current situation is beginning to take its toll on academic science. According to the Sir Gareth Robert's Review, which was published by the President of the Science Council in the UK in April 2002, the number of doctorates awarded to British students fell by $9 \%$ between the cohort of 1995/1996 and that of 1999/ 2000, and the UK is not alone in this situation. In addition, many young researchers are choosing to forgo the experience of a postdoc training period and are following a financially more rewarding path into business, government, journalism or industry. 'You have to be crazy to come out of a very selective French school and go into science', commented Moshe Yaniv of the Institut Pasteur in Paris on the situation of French students, who can easily earn up to $€ 5000$ more a month if they choose a position in government or industry. 'A mixture of low salaries and uncertainty about the future', he thinks, thus means that 'people don't want to face the difficulties of becoming a scientist'.

With the numbers of students entering the natural sciences dropping and an increasing number of researchers leaving academia for better paid positions elsewhere, politicians in various countries now fear that there will soon be a shortfall in the number of independent researchers and assistant professors in academic institutions. But it is not only a question of filling these positions. The postdoc

Table 2. Comparison of average salaries based on job advertisements posted in Nature, Science and the EMBO job database

\begin{tabular}{|c|c|c|}
\hline Country & $\begin{array}{l}\text { Annual } \\
\text { average } \\
\text { salary (in } € \text { ) }\end{array}$ & $\begin{array}{l}\text { Annual } \\
\text { minimum } \\
\text { salary (in } € \text { ) }\end{array}$ \\
\hline Switzerland & $45,452.00$ & $34,200.00$ \\
\hline Germany 1) & $37,416.00$ & $26,804.00$ \\
\hline UK & $35,892.00$ & $30,168.00$ \\
\hline Rest of EU & $32,496.00$ & $17,700.00$ \\
\hline US & $32,160.00$ & $27,000.00$ \\
\hline France & $22,320.00$ & $18,996.00$ \\
\hline \multicolumn{3}{|c|}{$\begin{array}{l}\text { 1) Most German salaries are based on the BAT IIa salary scale. } \\
\text { The average salary represents a } 31 \text { year old, married postdoc } \\
\text { with no children, the minimum salary represents an unmarried } \\
\text { postdoc with no children and no post-doctoral experience. }\end{array}$} \\
\hline
\end{tabular}




\section{analysis}

Table 3. Overview of fellowship programmes from European and North American funding agencies

\begin{tabular}{|c|c|c|c|c|c|c|}
\hline $\begin{array}{l}\text { Funding } \\
\text { Programme }\end{array}$ & $\begin{array}{l}\text { Eligibility and } \\
\text { limitations }\end{array}$ & $\begin{array}{l}\text { Salary based on an } \\
\text { unmarried fellow with } \\
\text { no children and no } \\
\text { postdoctoral experience }{ }^{1)}\end{array}$ & $\begin{array}{l}\text { Salary based on a married } \\
\text { fellow with } 2 \text { children and } \\
5 \text { years of postdoctoral } \\
\text { experience 2) }\end{array}$ & $\begin{array}{l}\text { Health } \\
\text { insurance }\end{array}$ & $\begin{array}{l}\text { Retirement } \\
\text { funds }\end{array}$ & $\begin{array}{l}\text { Family } \\
\text { allowances }\end{array}$ \\
\hline $\begin{array}{l}\text { Wellcome Trust } \\
\text { International } \\
\text { Research } \\
\text { Fellowship }\end{array}$ & $\begin{array}{l}\text { Any Postdoc who comple- } \\
\text { ted PhD or Masters in a UK } \\
\text { institution. Must not } \\
\text { return to home nation }\end{array}$ & $\begin{array}{l}\text { C34,282.00 } \\
\text { (travelling to Canada) }\end{array}$ & $\begin{array}{l}\text { C61,111.00 } \\
\text { (travelling to New York) }\end{array}$ & $\begin{array}{l}\text { mandatory } \\
\text { (part of the salary) }\end{array}$ & $\begin{array}{l}\text { (no with } \\
\text { some } \\
\text { exceptions) }\end{array}$ & yes \\
\hline $\begin{array}{l}\text { Wellcome Trust } \\
\text { Travelling } \\
\text { Research } \\
\text { Fellowships }\end{array}$ & $\begin{array}{l}\text { Postdoc of any } \\
\text { nationality to conduct } \\
\text { fellowship in a UK } \\
\text { institution }\end{array}$ & $\mathrm{C} 21,503.00$ & $€ 49,132.00$ & $\begin{array}{l}\text { mandatory } \\
\text { (part of the salary) }\end{array}$ & no & no \\
\hline $\begin{array}{l}\text { National Institutes } \\
\text { of Health } \\
\text { Individual Postdoc- } \\
\text { toral Fellowship }\end{array}$ & $\begin{array}{l}\text { Citizens and residents of } \\
\text { the US to conduct } \\
\text { fellowship inside or } \\
\text { outside the US }\end{array}$ & $627,494.00$ & $€ 39,451.00$ & no 3) & no & no \\
\hline $\begin{array}{l}\text { US National Science } \\
\text { Foundation } \\
\text { International Research } \\
\text { Fellowship Program }\end{array}$ & $\begin{array}{l}\text { Citizens and residents of } \\
\text { the US to conduct } \\
\text { research fellowship } \\
\text { outside the US }\end{array}$ & $€ 5,889.00$ & $€ 37,279.00$ & yes ( $€ 607$ per year) & no & yes \\
\hline $\begin{array}{l}\text { Swiss National } \\
\text { Fund Domestic } \\
\text { Fellowships }\end{array}$ & $\begin{array}{l}\text { Swiss citizens or } \\
\text { residents to conduct } \\
\text { fellowship in Switzerland }\end{array}$ & C51,100.00 & $657,900.00$ & $\begin{array}{l}\text { mandatory } \\
\text { (part of the salary) }\end{array}$ & yes & yes \\
\hline $\begin{array}{l}\text { Swiss National } \\
\text { Fund } \\
\text { International } \\
\text { Fellowships }\end{array}$ & $\begin{array}{l}\text { Swiss citizens or } \\
\text { residents to conduct } \\
\text { fellowship outside } \\
\text { Switzerland }\end{array}$ & $€ 27,300.00$ & $\epsilon 58,600.00$ & no & no & yes \\
\hline $\begin{array}{l}\text { Max-Planck-Institute } \\
\text { Minerva Fellowship } \\
\text { Program }\end{array}$ & $\begin{array}{l}\text { German and Israeli } \\
\text { citizens }\end{array}$ & $\epsilon 22,087.00$ & $\mathrm{C} 38,556.00$ & no & no & yes \\
\hline $\begin{array}{l}\text { Life-Science } \\
\text { Research Foundation } \\
\text { Postdoctoral } \\
\text { Fellowship }\end{array}$ & $\begin{array}{l}\text { US citizens to conduct } \\
\text { fellowship anywhere, } \\
\text { non-US citizens to con- } \\
\text { duct fellowship in the US }\end{array}$ & $€ 30,000.00$ & $€ 36,000.00$ & no 4) & no & no \\
\hline $\begin{array}{l}\text { The Weizmann } \\
\text { Institute of } \\
\text { Science }\end{array}$ & $\begin{array}{l}\text { Israell Citizens or } \\
\text { Residents to conduct } \\
\text { fellowship in Israel }\end{array}$ & $619,241.00$ & $\mathrm{C20}, 307.00$ & no & no & yes \\
\hline $\begin{array}{l}\text { Rothschild } \\
\text { Postdoctoral } \\
\text { Fellowships }\end{array}$ & $\begin{array}{l}\text { Israeli citizens or } \\
\text { residents to conduct } \\
\text { fellowship outside Israel }\end{array}$ & $\mathrm{C} 29,945.00$ & $C 43,680.00$ & no & no & yes \\
\hline $\begin{array}{l}\text { Marie Curie } \\
\text { Fellowships }\end{array}$ & $\begin{array}{l}\text { Citizen of most European } \\
\text { Countries 5) }\end{array}$ & $\begin{array}{l}\text { C20,400.00 } \\
\text { (travelling to Lithuania, } \\
\text { Latvia or Romania) }\end{array}$ & $\begin{array}{l}C 36,600.00 \\
\text { (travelling to the USA) }\end{array}$ & no & no & no \\
\hline $\begin{array}{l}\text { NSERC } \\
\text { Postdoctoral } \\
\text { Fellowships }\end{array}$ & $\begin{array}{l}\text { Canadian citizens or } \\
\text { residents to conduct } \\
\text { fellowship in an NSERC } \\
\text { institution }\end{array}$ & $\epsilon 22,655.00$ & $€ 22,655.00$ & no & no & no \\
\hline $\begin{array}{l}\text { BBSRC } \\
\text { David Phillip } \\
\text { Fellowship }\end{array}$ & $\begin{array}{l}\text { Postdoc of any } \\
\text { nationality to conduct } \\
\text { fellowship in the UK }\end{array}$ & $\epsilon 42,246.00$ & $€ 45,640.00$ & no & yes & no \\
\hline $\begin{array}{l}\text { EMBO } \\
\text { Long-Term Fellowship }\end{array}$ & $\begin{array}{l}\text { Citizen of an EMBO } \\
\text { Member State 6) }\end{array}$ & $\begin{array}{l}\text { €20,651.00 } \\
\text { (travelling to Croatia) }\end{array}$ & $\begin{array}{l}\text { C42,606.00 } \\
\text { (travelling to the USA) }\end{array}$ & no & no & no \\
\hline $\begin{array}{l}\text { Human Frontier } \\
\text { Science } \\
\text { Program } \\
\text { Long-Term Fellowship }\end{array}$ & $\begin{array}{l}\text { For Nationals of some } \\
\text { countries } 7)\end{array}$ & $\begin{array}{l}€ 28,360.00 \\
\text { (travelling to Canada) }\end{array}$ & $\begin{array}{l}€ 40,431.00 \\
\text { (travelling to Norway) }\end{array}$ & no 8 ) & no & $\begin{array}{l}\text { yes } \\
\text { (but only if } \\
\text { spouse has } \\
\text { no income) }\end{array}$ \\
\hline $\begin{array}{l}\text { Max-Planck- } \\
\text { Institute } \\
\text { Postdoctoral } \\
\text { Fellowship }\end{array}$ & $\begin{array}{l}\text { For postdocs of any } \\
\text { nationality to conduct } \\
\text { research at a Max- } \\
\text { Planck Institute }\end{array}$ & $C 26,804.00$ & $C 39,685.00$ & $\begin{array}{l}\text { mandatory } \\
\text { (part of the salary) }\end{array}$ & yes & yes \\
\hline $\begin{array}{l}\text { Deutsche } \\
\text { Forschungs- } \\
\text { gemeinschaft }\end{array}$ & $\begin{array}{l}\text { For postdocs of any } \\
\text { nationality. Some } \\
\text { restrictions for non- } \\
\text { Germans apply }\end{array}$ & $€ 26,804,00$ & $\epsilon 39,685.00$ & $\begin{array}{l}\text { mandatory } \\
\text { (part of the salary) }\end{array}$ & yes & yes \\
\hline MRC & $\begin{array}{l}\text { For postdocs of } \\
\text { any nationality }\end{array}$ & C31, 387.00 & $\mathrm{C} 38,917,00$ & $\begin{array}{l}\text { mandatory } \\
\text { (part of the salary) }\end{array}$ & yes & no \\
\hline INSERM & $\begin{array}{l}\text { For non-French postdocs } \\
\text { to conduct fellowship in } \\
\text { an INSERM institution }\end{array}$ & $\mathrm{C} 25,200.00$ & $C 34,800.00$ & yes & yes & yes \\
\hline $\begin{array}{l}\text { 1) Where salary is dependent o } \\
\text { 2) Where salary is dependent o }\end{array}$ & $\begin{array}{l}\text { In geographical location, the lowest salor } \\
\text { in geographical location, the highest sat }\end{array}$ & $\begin{array}{l}\text { iffered is presented } \\
\text { offered is presented }\end{array}$ & \multicolumn{4}{|c|}{$\begin{array}{l}\text { 6) Austria, Belgium, Croatia, Crech Repubic, Denmark, Finland, France, Germany, Greece, } \\
\text { Hungary, Iceland, Ireland, Issael, thaty, The Nethertands, Norway, Poland, Portugal, Slovenia, } \\
\text { Spain, Sweden, Switzerland, Turkey, United Kingdom }\end{array}$} \\
\hline \multicolumn{3}{|c|}{$\begin{array}{l}\text { 3) Do provide a fat institutional allowance of CS,635 that can cover the costs of health } \\
\text { insurance, equipment, supplies and other training costs }\end{array}$} & \multicolumn{4}{|c|}{$\begin{array}{l}\text { 7) Austria, Belgium, Canada, Denmark, Finland, France, Germany, Greece, Italy, Japan, } \\
\text { Luxembourg, The Netheriands, Pertugal, The Republic of Ireland, Spain, Sweden, Switzeriand, } \\
\text { United Kingdoen and USA. }\end{array}$} \\
\hline \multicolumn{3}{|c|}{$\begin{array}{l}\text { 5) Austria, Belgum, Bulgaria, Cyprus, Czech Republic, Denmark, Estonia, Fintand, France, } \\
\text { Germany, Greece, Hungary, Iceland, Ireland, Israel, Italy, Latvia, Uichtenstein, Uthuania, } \\
\text { Luxembourg, Maita, The Netherlands, Norway, Poland, Portugal, Romania, Slovakia, Slowenia, } \\
\text { Sweden, Switzerland, and the United Kingdom }\end{array}$} & $\begin{array}{l}\text { 8) Up to } 66,135 \text { per year is provided t. } \\
\text { used to contribute towards health it }\end{array}$ & $\begin{array}{l}\text { cover scientific research costs, } \\
\text { urance }\end{array}$ & and this can be & \\
\hline
\end{tabular}


community performs the vast majority of the research conducted in academic institutions - this magic moment of discovery, this eureka moment smiles mostly on our younger scientists', stated Gottfried Schatz, President of the Swiss Science and Technology Council. The demise of this valuable resource thus represents a far greater loss of scientific potential, creativity and progress and it is going to hit Europe the hardest. Not only is the whole of the Pacific Rim a massive human resource for US universities, but many European postdocs are also lured across the Atlantic by better research resources and better career prospects-the socalled brain drain. Furthermore, the US government recently doubled the budget of the US National Institutes, which will eventually result in higher salaries for postdocs working in the USA and may thus contribute further to the steady migration of scientists from Europe.
As a result of studies, such as the Sir Gareth Roberts Review, 'there is now a broad recognition that we will not get people into the profession if we do not pay reasonable salaries', said Niall Dillon, a group leader from the MRC Clinical Sciences Centre in London, UK. But while 'the situation in Britain has improved in the last couple of years as the MRC and the Wellcome Trust have both increased salaries', he warns that the problem in the rest of Europe 'is much greater'. Indeed, there is still a long way to go and there are no easy answers. Coutinho considers that it 'is unacceptable that people with 10 to 15 years of education end up with these levels of salaries'. Although salaries in the UK and the USA are beginning to rise, there are many other issues, particularly the problem of inflexible pension schemes, that urgently need to be addressed. 'The solution for this, like for most things, is political', said Coutinho and thinks that these basic problems have to be solved first to attract more students to the natural sciences. Yaniv agrees: 'Instead of spending money on futile programmes, [the EC] should find a way to pay postdocs and for a longer time'. He does, however, admit that it is not easy for governments to raise budgets at the drop of a hat and that merely calling for more government funding is not the answer.

One fact, however, is clear. The postdoc system has proven immensely successful over the last few years at producing scientific results and well-trained scientists and replacing it is out of the question. Changes are needed but, as Niall Dillon said, 'the system works and is a successful model for research. It created a revolution in the biosciences and we should do what we can to improve it'.

\section{Jack Parker}

DOI: 10.1093/embo-reports/kvf229

\section{When will the bear move on?}

\section{The current problems of the biotechnology industry are not solely a reflection of the whole market but are also caused by some specific problems}

\begin{abstract}
The year 2002 has not been kind to biotechnology: the industry has lost nearly half its value since January. In the USA alone, the Nasdaq Biotechnology Index is down by $49 \%$ after a 2 year rally that ended in April 2001, when the Nasdaq Biotech Index had gained $60 \%$ in comparison with Nasdaq losses of $24 \%$. But, in general, 2002 has been one of the worst years ever on Wall Street, not just for biotechnology. On September 24, the Nasdaq slipped to its lowest point in 6 years and, on the same day, the Dow Jones hit its lowest low in 4 years. And there are still no signs of recovery. Recently, the New York Times noted that 'there are more signs [than a few months ago] that recovery is weaker than expected and that [as] optimistic earnings expectations for the third quarter are fading, the list of concerns is growing'. Besides not knowing when the bear will make way for the bull once more, some
\end{abstract}

wonder if biotechnology's current slide is just one aspect of a general economic downturn or if the industry has some specific problems.

Clearly, various corporate scandals such as Enron and, closer to home, ImClone Systems (New York, NY) are playing a role in biotechnology's current

Stock slides can be contagious: many companies with drugs in the same areas have hit snags and their stocks have also slid downwards

travails, but the cumulative effects of a weak economy pummelled by the events of September 11 2001, an increasing chance of war with Iraq, unsteady oil prices and falling interest rates are exerting their toll on the biotechnology market.
In addition, recent rejections of new drug applications (NDAs) from various biotechnology companies by the US Food and Drug Administration have led to a general downturn of the stocks of companies with similar drugs in the pipeline.

Furthermore, bad news from clinical trials and new FDA regulations for drugs in development have also meant plunges in stock prices. Failures of phase III trials to meet endpoints are more numerous than ever, including Dendreon's (Seattle, WA) Provenge for prostate cancer, Pharmacia's (Peapack, NJ) SU-5416 to treat colon cancer and Cubist Pharmaceuticals' (Lexington, MA) new antibiotic Cidecin; but this is balanced by the fact that there currently are a record number of biotechnology drugs in late-stage development. Unfortunately, stock slides can be contagious: many companies with drugs in the same areas have hit snags and their stocks have also slid downwards-guilt by association. 